\title{
RESEARCH IN SPORT PHYGICAI A \\ A role of DAP12, an activating-type immunoregulatory molecule in skeletal muscle regeneration
}

Autor(es): $\quad$ Sakamoto, Yuzuru; Sugahara-Tobinai, Akiko; Takai, Toshiyuki

Publicado por: Imprensa da Universidade de Coimbra

URL persistente:

URI:http://hdl.handle.net/10316.2/44098

DOI:

DOI:https://doi.org/10.14195/2182-7087_ex2018_35

Accessed : $\quad$ 26-Apr-2023 07:33:39

A navegação consulta e descarregamento dos títulos inseridos nas Bibliotecas Digitais UC Digitalis, UC Pombalina e UC Impactum, pressupõem a aceitação plena e sem reservas dos Termos e Condições de Uso destas Bibliotecas Digitais, disponíveis em https://digitalis.uc.pt/pt-pt/termos.

Conforme exposto nos referidos Termos e Condições de Uso, o descarregamento de títulos de acesso restrito requer uma licença válida de autorização devendo o utilizador aceder ao(s) documento(s) a partir de um endereço de IP da instituição detentora da supramencionada licença.

Ao utilizador é apenas permitido o descarregamento para uso pessoal, pelo que o emprego do(s) título(s) descarregado(s) para outro fim, designadamente comercial, carece de autorização do respetivo autor ou editor da obra.

Na medida em que todas as obras da UC Digitalis se encontram protegidas pelo Código do Direito de Autor e Direitos Conexos e demais legislação aplicável, toda a cópia, parcial ou total, deste documento, nos casos em que é legalmente admitida, deverá conter ou fazer-se acompanhar por este aviso. 


\section{ANNALS OF RESEARCH IN SPORT AND PHYSICAL ACTIVITY}




\section{A ROLE OF DAP12, AN ACTIVATING-TYPE IMMU- NOREGULATORY MOLECULE IN SKELETAL MUSCLE REGENERATION}

Yuzuru Sakamoto'; Akiko Sugahara-Tobinai²; Toshiyuki Takai²

KEY WORDS: skeletal muscle, DAP12, M1/M2-type macrophage, ITAM.

\section{INTRUDUCTION}

Injured muscle regeneration and maintenance of skeletal muscle are integrated events by various related cells and humoral factors, but those regulatory mechanisms remain unclear. Recently, there are many reports on the involvement of immune cells in skeletal muscle regeneration, and it has been shown that not only the initiation of inflammation at the injured site but also direct involvement in the regeneration of injured muscle ${ }^{(1)}$. In this study, we focused on the activation signal adapter molecule DNAX activating protein of 12 $\mathrm{kDa}$ (DAP12), which was shown to be involved in cell differentiation and bone metabolism of myeloid cells ${ }^{(2,3)}$. The purpose of this study was to examine whether DAP12 mediated signals in immune cells affect injured skeletal muscle repair and regeneration process.

\section{METHODS}

Pharmacological muscle injuries using cardiotoxin were induced in the triceps surae muscle of C57BL/6 wild type and DAP12-deficient mice, and injured muscle samples from the early to the recovery phase were sequentially collected. Thereafter, immunohistological analysis, flow cytometry analysis and qPCR gene expression analysis were performed.

\footnotetext{
1 Department of Human Science, Faculty of Liberal Arts, Tohoku Gakuin University.

2 Department of Experimental Immunology, Institute of Development, Aging and Cancer, Tohoku University. Email: ysakamoto@mail.tohoku-gakuin.ac.jp
} 


\section{RESULTS}

Retardation of muscle regeneration was observed in DAP12-deficient mice. In addition, $\mathrm{F} 4 / 80$ + cells localized in injured muscle were reduced in DAP12-deficient mice. Moreover, there was a change in the cell polarity of M1-/M2-type of F4/80+ cells in DAP12-deficient mice.

\section{CONCLUSION}

It was suggested that DAP12 mediated signals might be involved in the regulatory mechanism of skeletal muscle regeneration by controlling recruitment and differentiation of F4/80+ cells to injured muscles.

\section{REFERENCES}

1. Burzyn, D., Kuswanto, W., Kolodin, D., Shadrach, Jennifer L., Cerletti, M., Jang, Y., . . Mathis, D. (2013). A Special Population of Regulatory T Cells Potentiates Muscle Repair. Cell, 155(6), 1282-1295.

2. Koga, T., Inui, M., Inoue, K., \& Kim, S. (2004). Costimulatory signals mediated by the ITAM motif cooperate with RANKL for bone homeostasis. Nature, 428(6984), 758.

3. Kaifu T, Nakahara J, Inui M, Mishima K, Momiyama T, Kaji M, Sugahara A, Koito H, Ujike-Asai A, Nakamura A, Kanazawa K. Osteopetrosis and thalamic hypomyelinosis with synaptic degeneration in DAP12-deficient mice. Journal of Clinical Investigation. 2003 Feb 1;111 (3):323. 